\title{
DESCRIPTION OF AN ECOTECHNICAL METHOD, PROPOSED FOR THE HÂRTIBACIU RIVER ALONG THE SECTOR IN AGNITA, SIBIU COUNTY
}

\author{
Răzvan VOICU * and Liliana VOICU ** \\ * National Institute of Hydrology and Water Management, Department of Eco-Hydrology, București- \\ Ploiești Street 97, Romania, RO-013686, rzvnvoicu@yahoo.com \\ ** National Institute of Hydrology and Water Management, Department of Eco-Hydrology, București- \\ Ploiești Street 97, Romania, RO-013686, biolili_80@yahoo.com
}

DOI: 10.1515/trser-2015-0012

KEYWORDS: Romania, Olt River basin, ecosystem functions, water, stream, birds, vegetation, flow.

\section{ABSTRACT}

The Hârtibaciu River is channelled (covered by concrete) near the city of Agnita and represents the confluence of numerous sources of local pollution having a negative impact both qualitatively and quantitatively. Lack of riparian vegetation gives the Hârtibaciu River an unpleasant aspect and cannot provide an efficient filter.

This ecotechnical method helps to protect the special protected areas (SPAs) into Hârtibaciu River basin and to clean the river in the city of Agnita. By the means of this method the quality of the Cibin River can also be improved, as the Hârtibaciu River is a tributary of it.

RÉSUMÉ: Description de la méthode écotechnique proposée pour la Rivière de Hârtibaciu dans le secteur de la ville d'Agnita.

La rivière de Hârtibaciu est bétonnée sur toute la longueur de sa traversée de la ville d’Agnita et elle est le collecteur de nombreuses sources de pollutions locales ayant un impact négatif sur la rivière, autant qualitativement que du point de vue quantitatif. Le manque de végétation riparienne donne à cette rivière un aspect déplaisant et ses eaux sont filtrées inefficacement.

La méthode écotechnique proposée aide à protéger les zones de protection spéciales établies dans le bassin de la rivière de Hârtibaciu ainsi qu'à nettoyer la rivière dans son secteur citadin à Agnita. Un autre résultat de l'application de cette méthode est la possible amélioration de la qualité de la rivière Cibin, collecteur des eaux de Hârtibaciu.

REZUMAT: Descrierea metodei ecotehnice, propusă pentru râul Hârtibaciu, pe sectorul de apă, aflat în dreptul localităţii Agnita.

Râul Hârtibaciu este canalizat (betonat) în dreptul localității Agnita și colectează numeroase surse de poluare locale, cu impact negativ asupra calităţii apei şi comunităţilor acvatice. Lipsa vegetaţiei ripariene determină ineficienţa proceselor de filtrare a poluanţilor şi conferă râului Hârtibaciu un aspect inestetic.

Metoda ecotehnică descrisă contribuie la managementul eficient al zonelor de protecție specială situate în bazinul hidrografic al râului Hârtibaciu și la creştrea capacităţii de epurare a apelor râului pe teritoriul oraşului Agnita. De asemenea, şi calitatea râului Cibin, poate fi ameliorată prin această metodă, Hârtibaciul fiind un tributar al acestuia. 


\section{INTRODUCTION}

The subject of this case study proposes an ecotechnical measure consisting of: capture (measuring), using channels inside the concrete banks, of urban pollution sources, development (measuring) of an ecological river bed equipped with a wetland and of some network of wetlands as a habitat for many protected bird species existing on the Hârtibaciu Plateau.

Along the lotic sector which passes through the city of Agnita, the Hârtibaciu River is almost completely dammed (Figs. 1 and 2) with solid concrete walls on the river banks.

Because the sources of pollution (industrial and domestic) from the city of Agnita (Fig. 3) and a complete lack of riparian vegetation, basic elements that support the selfcleaning of a lotic ecosystem were almost totally destroyed.

There are many sources of pollution that penetrate the waters directly into the river Hârtibaciu River without being treated.

\section{METHOD}

This water sector was chosen because it is almost completely determined by the Hârtibaciu water's course, within the city of Agnita, and also because of the destruction of various species of bird and fish habitats in the city and also downstream the city.

In order to finalize the ecological reconstruction of the Hârtibaciu River, the new river bed should be protected from any source of pollution, so the sources of pollution (city polluted water) must be captured through parallel channels built inside the concrete banks (Fig. 4).

Sizing parallel channels will be done according to the evacuated water flow (industrial and domestic) into the Hârtibaciu River.

In this case, it is not necessary to perform the un-concreting procedure on the river banks, as the Hârtibaciu River can be rebuilt ecotechnically within these banks.

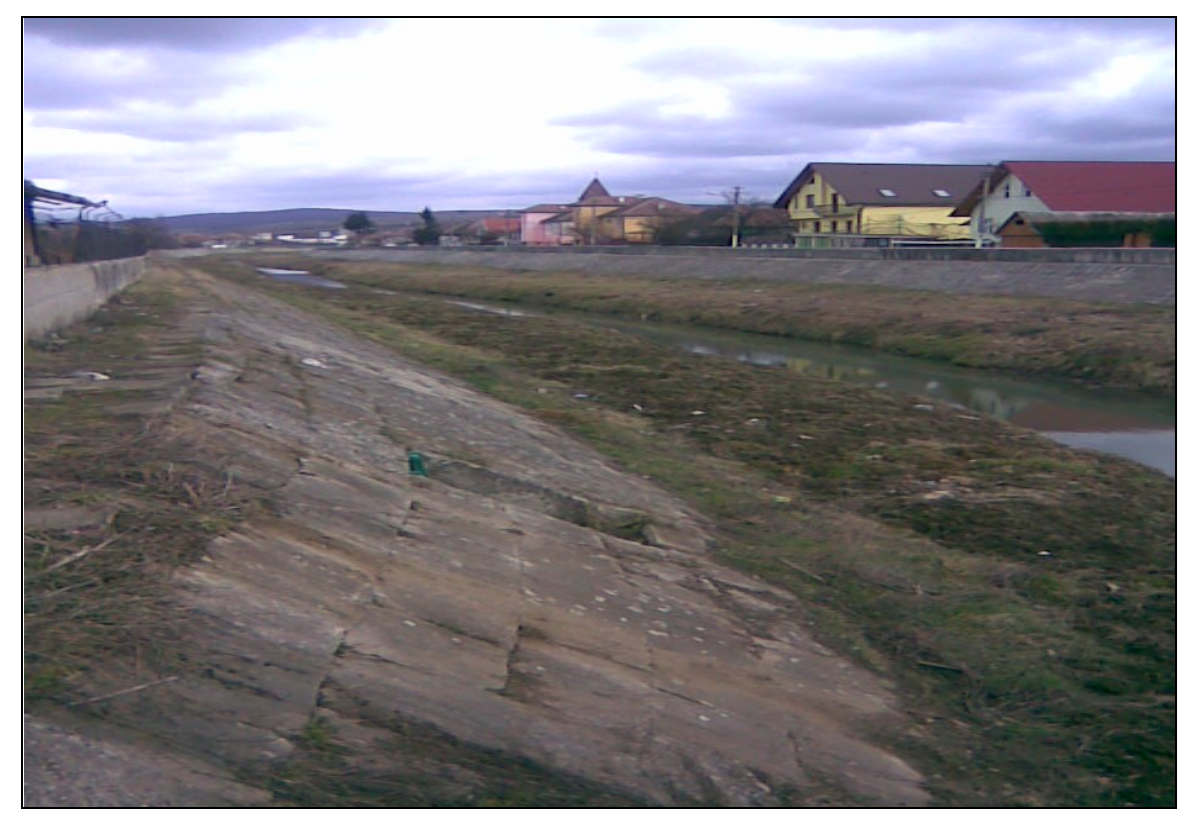

Figure 1: Hârtibaciu River (http://ro.wikipedia.org). 


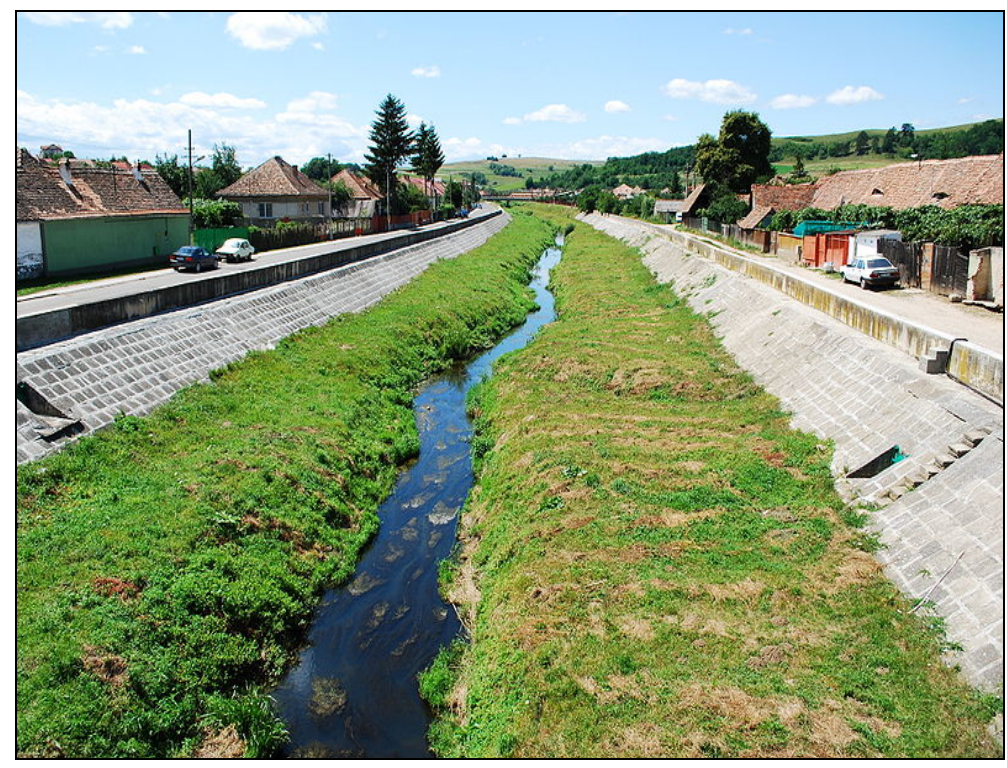

Figure 2: Hartibâciu River (http://ro.wikipedia.org).

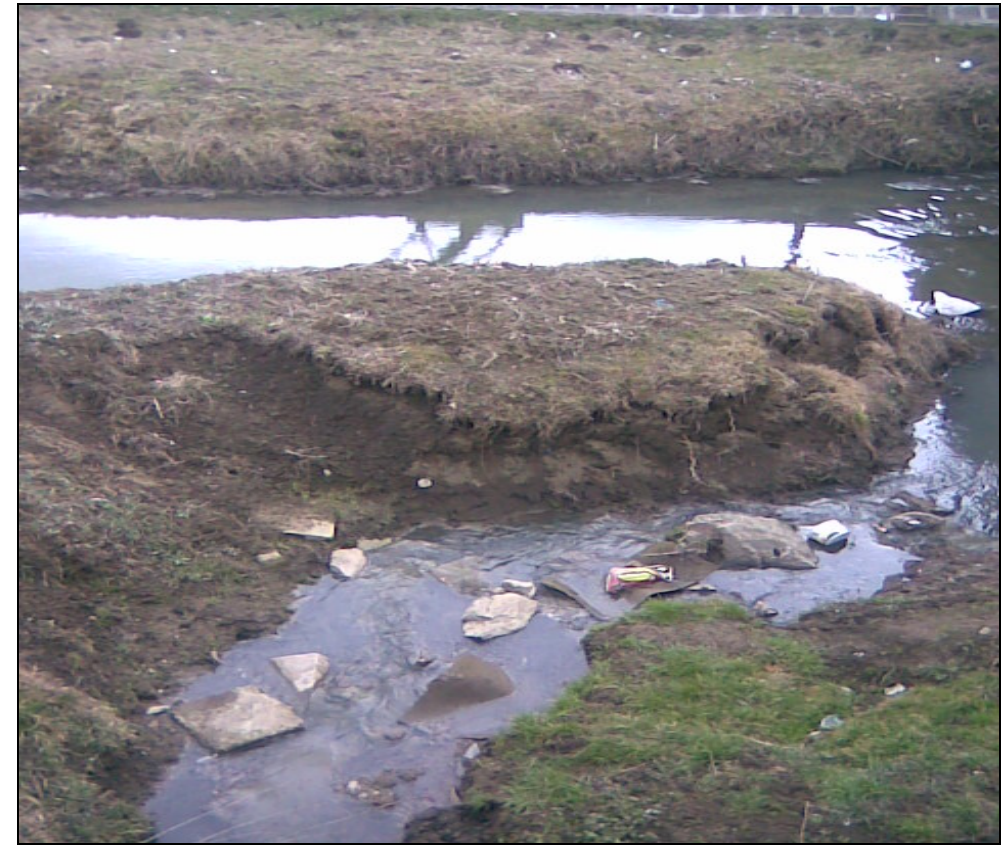

Figure 3: Pollution source, Hârtibaciu River.

\section{RESULTS AND DISSCUSION}

The river water quality at the exit of Hârtibaciu, Agnita is the fourth category.

The Hârtibaciu River flow area will be constructed as meander belts by wooden concrete to resist the floods.

In the immediate vicinity of the Hârtibaciu River, wetlands will be built and linked to the river through a system of channels (Fig. 5). 


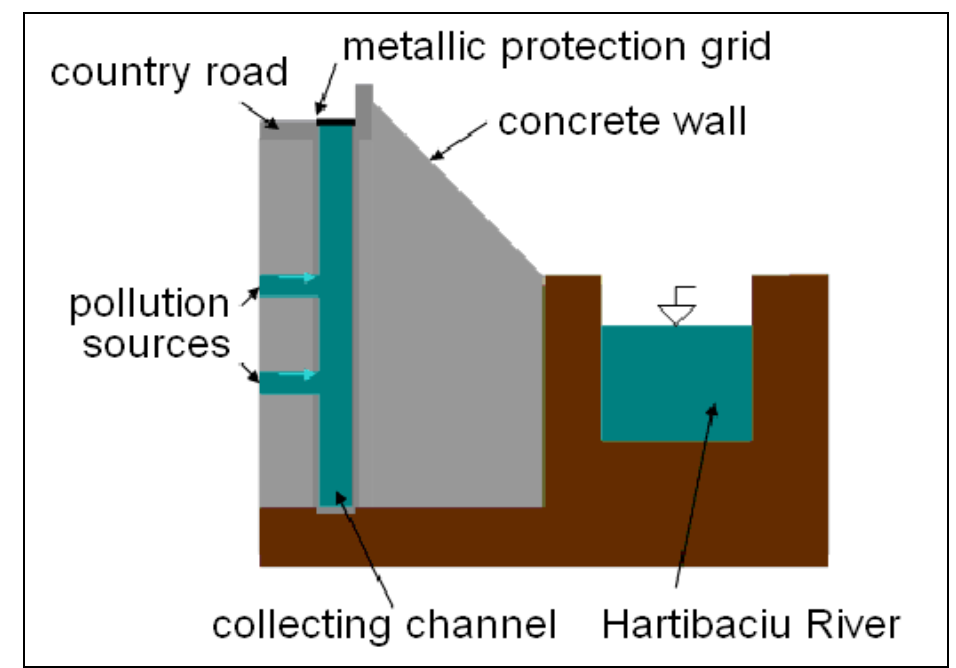

Figure 4: Collecting channel located on the right bank of Hârtibaciu River (scheme).

A meandering river bed with green sides, having the form of an inclined plane (Cibin River) are necessary to be created. Water flow area will be made of wood or concrete according to regional flood frequency and amplitude. Various fast-growing woody species (alder, willow, etc.) but also herbaceous species having fascicular roots (sedge, fescue, etc.) will be planted in line or in the form of rhombs, along these banks. The banks will filled up with soil up to the middle height of the dam protection (Fig. 5).

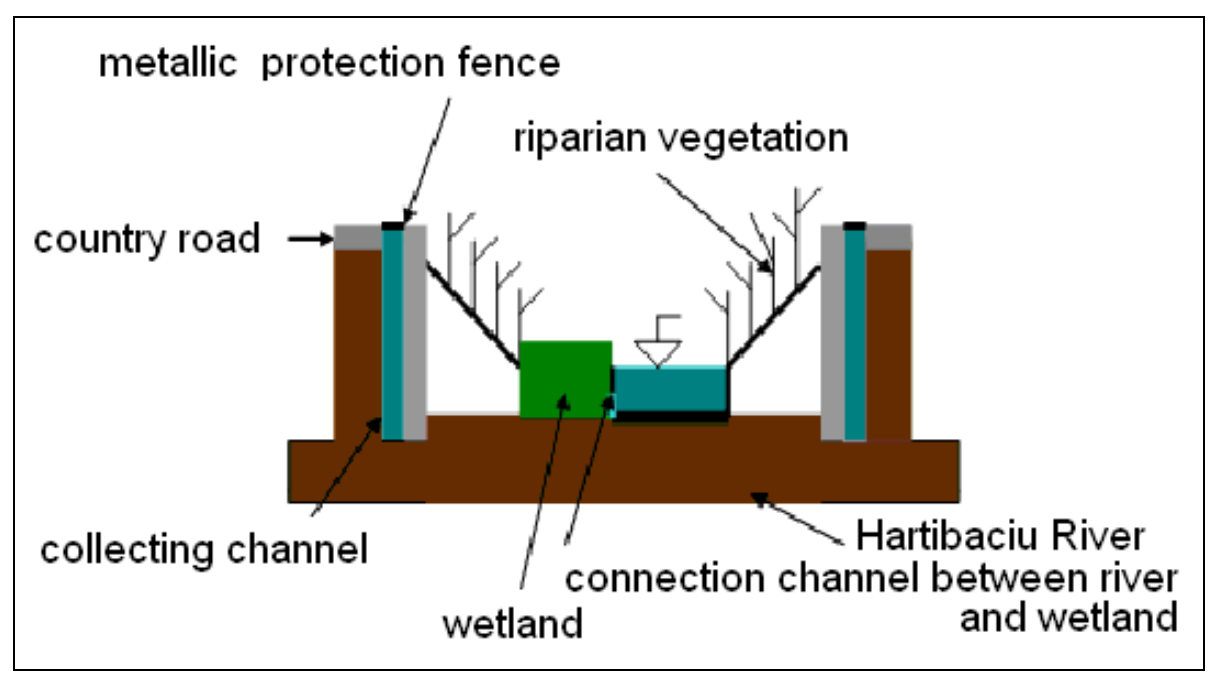

Figure 5: Ecotechnical arrangement of Hârtibaciu River in the city of Agnita - cross section (orientative scheme).

This ecotechnical method is suggested for the riverbed sector effective starting to 400 $\mathrm{m}$ length up to the complete river sector arrangement. The river sector which passes through Agnita will be completed at the exit of the city. The collecting channels must have the same slope as the Hârtibaciu River. The ecotechnical reconstruction of the Hârtibaciu River will also continue downstream the city of Agnita, having about $500 \mathrm{~m}$ length and creating riparian areas and wetlands. 


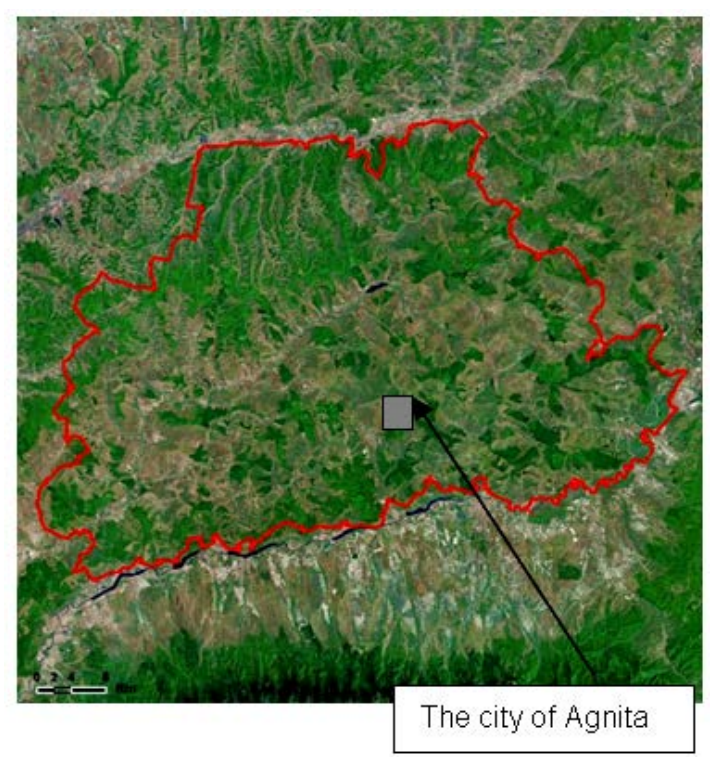

Figure 6: Hârtibaciu Plateau - Satellite image (source: Landsat Image @ NASA).

According to GD 1284/2007, the Hârtibaciu Plateau (Fig. 6) has been declared a special area of aviafaunistic protection becoming a bird protection area, as a part of the European Natura 2000 network in Romania. This SPA covers parts of the territory of the counties of Brașov, Sibiu and Mureș, 39 municipalities and the five cities of Agnita, Dumbrăveni, Făgăraş, Sighișoara and Rupea, being in size, together with Sighișoara-Târnava Mare area the second protected area in the country, after the Danube Delta. Most of this area is in Sibiu County, in the Hârtibaciu Valley (Fig. 7).

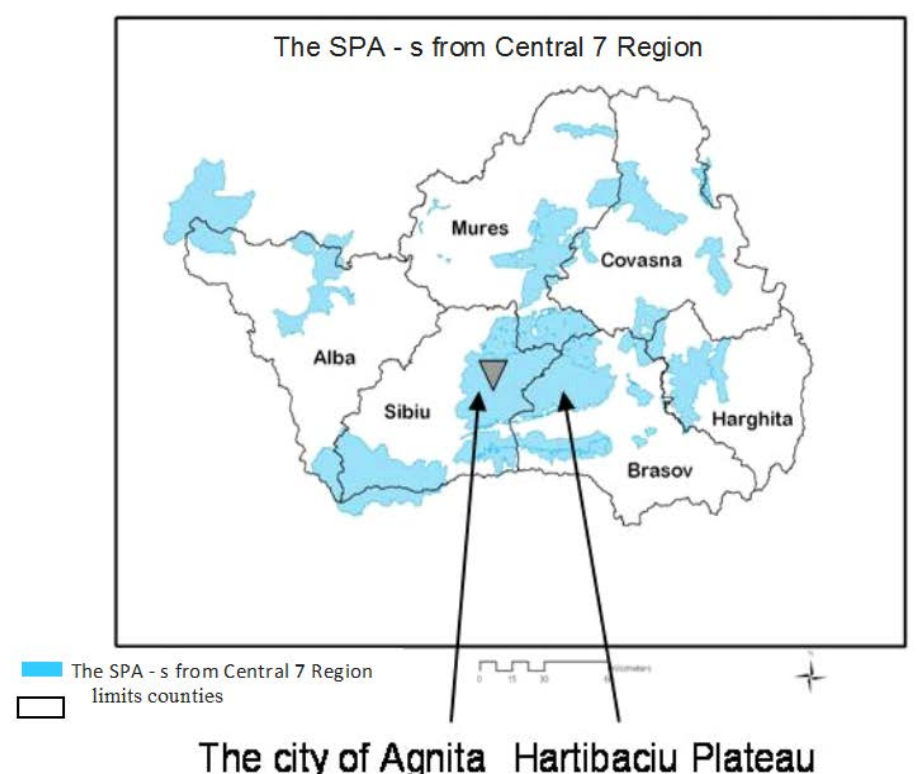

Figure 7: Hârtibaciu Plateau RO SPA 0099 (http://www.arpm7c.ro/img/spa\%20web.jpg). 
The aim of this special area for the protection of birds has been the preservation of 32 bird species: Alcedo athis (Kingfisher), Anthus campestris (Tawny Pipit), Aquila pomarina (The Lesser Spotted Eagle), Aythya nyroca (The Ferruginous Duck), Botaurus stellaris (The Eurasian Bittern), Bubo bubo (The Eurasian Eagle-owl), Caprimulgus europaeus (The European Nightjar), Chlidonias hybridus (The Whiskered Tern), Chlidonias niger (The Black Tern), Ciconia ciconia (The White Stork), Ciconia nigra (The Black Stork), Circaetus gallicus (The Short-toed Eagle), Circus aeruginosus (The Marsh Harrier), Circus cyaneus (The Hen Harrier), Crex crex (The Corncrake), Dendrocopos leucotos (The White-backed Woodpecker), Dendrocopos medius (The Middle Spotted Woodpecker), Dendrocopos syriacus (The Syrian Woodpecker), Dryocopus martius (The Black Woodpecker), Egretta alba (The Great Egret), Falco vespertinus (The Red-footed Falcon), Himantopus himantopus (The Black-winged Stilt), Lanius collurio (The Red-backed Shrike), Lanius minor (The Lesser Grey Shrike), Lullula arborea (The Woodlark), Nycticorax nycticorax (Black-crowned Night-heron), Pernis apivorus (The Honey Buzzard), Philomachus pugnax (The Ruff), Picus canus (The Greyheaded Woodpecker), Sterna hirundo (The Common Tern), Strix uralensis (The Ural Owl) and Tringa glareola (The Wood Sandpiper). The area hosts a significant number of typical species. Here, the most important population of The Lesser Spotted Eagle and The Honey Buzzard has its nests, the highest density being achieved at the south of the Hârtibaciu Valley. The Corncrake (Crex crex) population is globally significant (over 20 pairs).

Downstream of the city of Agnita, there are several areas where dozens of species of protected birds, five species of fish (Barbus meridionalis, Cobitis taenia, Gobio kesslerii, Rhodeus sericeus amarus, and Sabanejewia aurata) and the macroinvertebrates species food of fish are hosted but, due to increasing pollution, their numbers have decreased drastically. Riparian vegetation destruction, disposal of garbage and the building of various illegal constructions along the Hârtibaciu River banks led to additional pollution of the river and caused the disappearance of many habitats for various species of birds. Therefore, downstream of the city of Agnita, near the city, rectangular artificial wetlands to purify the polluted water from sewers must be constructed (Fig. 8). A part of the water entering the wetlands will reach the Hârtibaciu River through the connection channels (Fig. 8).

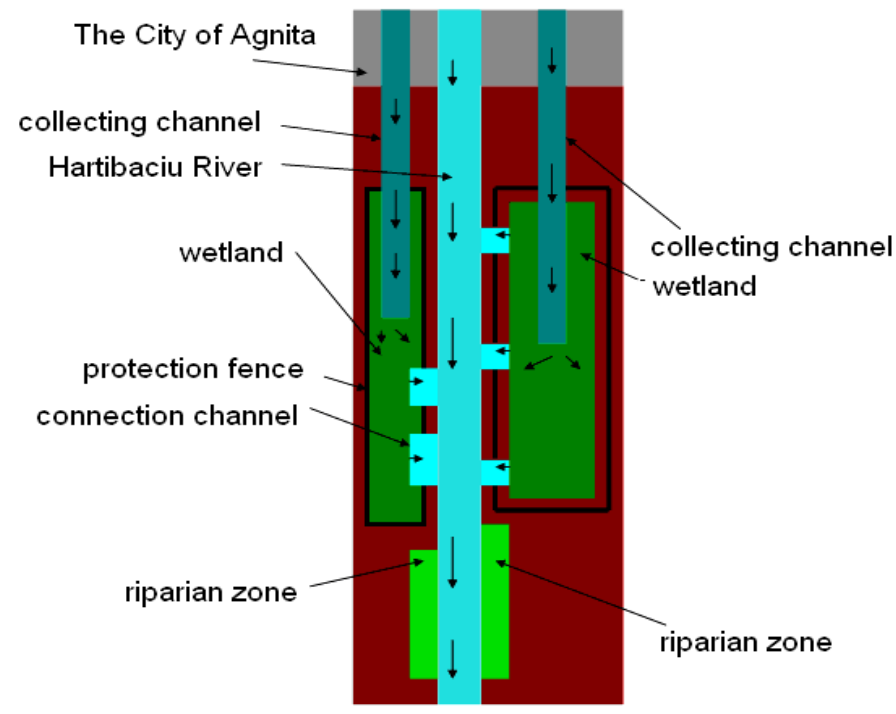

Figure 8: Ecotechnical arrangement of Hârtibaciu River downstream the city of Agnita - cross section (orientative scheme). 
Downstream of the wetlands, riparian zones, extremely important to stabilize banks, will be developed (Fig. 8). All these ecotechnical arrangements using the ecological scrubber system of wetlands and riparian zones will cause a change in water quality of the Hârtibaciu River. This will generate an increase in local biodiversity of the river, which is essential to ecosystem functioning of these areas. Wetlands and riparian areas must be protected using metallic fences. An undeveloped ecotechnical arrangment of this river completely destroys the habitats of various species of birds and fish downstream the city. Ecotechnical arrangement of the Hârtibaciu River in the city of Agnita will lead to water quality improvement by the means of bioconversion and accumulation, production of organic matter for aquatic ecosystems and will safely preserve flora and fauna for the habitat (Fig. 9). Any ecotechnical arrangement of the Hârtibaciu River along the city of Agnita has no ecological value as long as there are sewer overflows into the river.

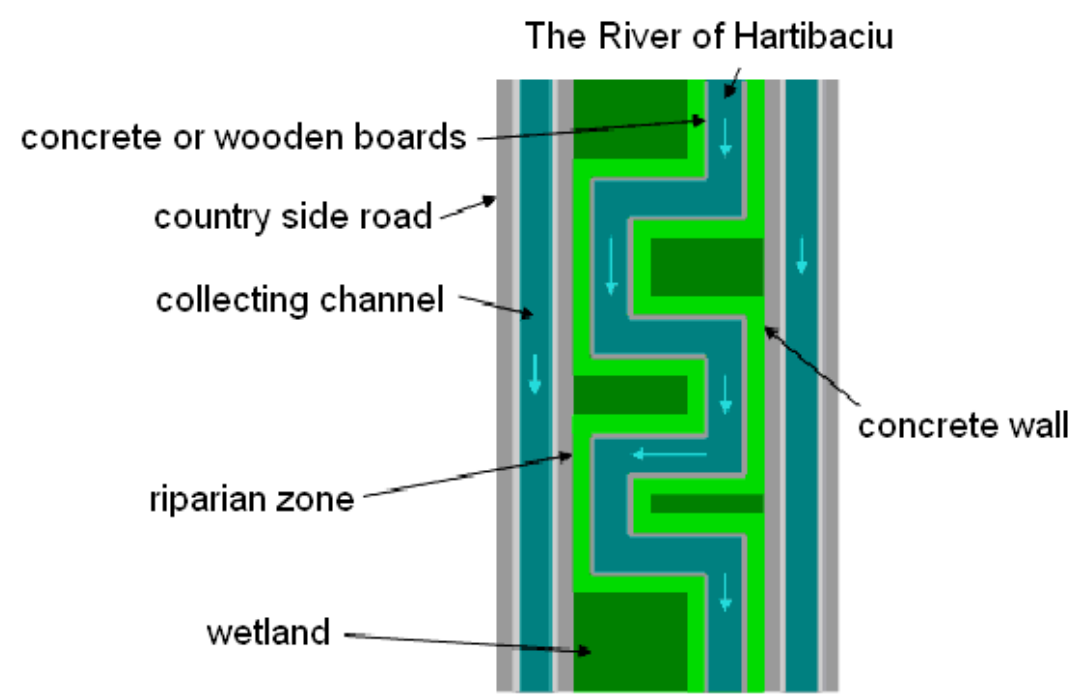

Figure 9: Ecotechnical arrangement of Hârtibaciu River in the city of Agnita - cross section (orientative scheme).

\section{CONCLUSIONS}

This ecotechnical method helps both to protect the SPAs into the Hârtibaciu River basin and to clean the river in the city of Agnita.

By the means of this method, the quality of Cibin River can be also improved as Hatibaciu River is a tributary of it. 


\section{SELECTIVE REFERENCES}

1. Curtean-Bănăduc A. and Bănăduc D., 2012 - Eco-sanitaţia alternativă pentru managementul durabil al nutrienţilor şi resurselor de apă, în Apa resursă fundamentală a dezvoltării durabile, Metode şi tehnici neconvenţionale de epurare şi tratare a apei, I, Oprean L. (ed.), Editura Academiei Române, 433-437. (in Romanian)

2. Curtean-Bănăduc A. and Bănăduc D., 2012 - Aspecte privind impactul deversării apelor uzate asupra sistemelor ecologice lotice receptoare, în Apa resursă fundamentală a dezvoltării durabile, Metode şi tehnici neconvenţionale de epurare şi tratare a apei, II, Oprean L. (ed.), Editura Academiei Române, 393-416. (in Romanian)

3. Curtean-Bănăduc A., Schneider-Binder E. and Bănăduc D., 2014 - The importance of the riverine ligneous vegetation for the Danube Basin lotic ecosystems, in Cianfaglione K. (ed.), L’importanza degli Alberi e del Bosco, Cultura, scienza e coscienza del territorio, Temi Ed., Trento, Italia, ISBN: 978-88-973772-63-9, I-II, 187-210.

4. Curtean-Bănăduc A., Bănăduc D. and Bucşa C., Watershed Management (Transylvania, Romania) - implications, risks, solutions, Strategies to Enhance Environmental Security in Transition Countries, NATO Security trough Science Series - C: Environmental Security, Springer, 225-238, ISBN 978-1-4020-5995-7, 2007.

5. David L. R., 1994 - A classification of natural rivers, Wildland Hydrology, 157649 U. S. Highway, 160, Pagosa Springs, CO 81147.

6. Federal Interagency Stream Restoration Working Group, 1998 - Stream Corridor Restoration: Principles, Processes and Practices, 2-23.

7. Frothingham K. M., Rhoads B. L. and Herricks E. E., 2001 - Stream geomorphology and fish community structure in channelized and meandering reaches of an agricultural stream, Understanding Geomorphic Processes and Riverine Habitat, Washington D.C.: American Geophysical Union, Water and Science Application, 4, 105-117.

8. Galvánek D., Kadlečík J., Dostalova A., Dukaz I., Gruber T., Scmotzer A., Schmidt A., Pokorni F., Zsembery Z., Egri C., Szary A., Pokynchereda V., Gubko V., Felzbaba-Klushina L., Schneider E., Curtean-Bănăduc A., Bănăduc D. and Lazarevic P., 2014 - Development of Common Integrated Management Measures for Key Natural Assets in the Carpathians, in Development of Common Integrated Management Measures for Key Natural Assets in the Carpathians, Work Package 4, Integrated Management of Biological and Landscape Diversity for Sustainable Regional Development and Ecological Connectivity in the Carpathians, WWF Danube-Carpathian Programme, Vienna, Appleton M. R. and Meyer H., (eds), 72-103, ISBN 978-9958-021-01-3.

9. Kondolf G. M. and Micheli E. R., 1995 - Evaluating stream restoration projects, Environmental Management, 19, 1, 1-15.

10. Palmer M. A. and Bernhardt E. S., 2006 - Hydroecology and river restoration: ripe for research and synthesis, W03S07; 10.1029/2005, WR004354, Water Resources Research, 42, 3.

11. Power M. E., Dietrich W. E. and Finaly J. C., 1996 - Dams and downstream aquatic biodiversity: potential food web consequences of hydrologic and geomorphic change, Environmental Management, 20, 6, 887-895.

12. Rosgen D. L., 1996 - Applied River Morphology, Wildland Hydrology Books, Pagosa Springs, Colorado, 5-30.

13. Schiechtl H. M. and Stern R., 1996 - Water Bioengineering Techniques for Watercourse Bank and Shoreline Protection, Cambridge, Blackwell Science Inc. 223.

14. Stream Bank Erosion, NRCS Field Office Technical Guide, 2003 - United States Department of Agriculture, 2-20.

15. U.S. Environmental Protection Agency, Office of Water, River Corridor and Wetland Restorationhttp://www.epa.gov/owow/wetlands/restore/

16. U.S. Environmental Protection Agency, 2008 - Watershed Assessment of River Stability and Sediment Supply (WARSSS) website: www.epa.gov/warsss/sedsource/streamero.htm

17. * http://www.arpm7c.ro 